\title{
Study on the Gembrong Goat Inbreeding in Tumbu Village, Indonesia
}

\author{
Muhammad Ridho ${ }^{1}$, and Widya Pintaka Bayu Putra ${ }^{2, *}$ \\ ${ }^{1}$ Faculty of Agriculture, Sebelas Maret University, 57125 Surakarta, Indonesia \\ ${ }^{2}$ Research Center for Biotechnology, Indonesian Institute of Science, 16911, Cibinong, Indonesia
}

\begin{abstract}
Gembrong goat is an Indonesian breed originating from Bali Province that is very rare, having a high level of inbreeding. The inbreeding coefficient (Fis), inbreeding rate (IR), and inbreeding probability (PI) values of Gembrong goat were estimated in Tumbu village, Bali province, Indonesia. Previous studies provide data on the pedigree records of goats in 2015. According to research, the Fis value of Gembrong goats at Tumbu village was 0.413 , putting them in the high category $(\mathrm{Fx}>0.125)$. The IR value in the Gembrong population at Tumbu village was 0.025 , putting it in the high group (IR > 0.020). The PI value in the F1 Gembrong population was 0.184 , which was in the low category (PI 0.50). In conclusion, the elevated Fis and IR values in Gembrong goats were caused by a small population size. In the future, the Gembrong goat recording system will be critical for reducing inbreeding.
\end{abstract}

Keywords: Gembrong goat, inbreeding, Tumbu village

\section{Introduction}

The gembrong goat (Capra aegagrus) is an Indonesian native goat that originated on the island of Bali. This goat is designated an Indonesian goat breed by the Ministry of Agriculture Decision No: 696/Kpts/Pd.410/2/2013. The Gembrong goat has adult weights of $20 \mathrm{~kg}$ (female) and $40 \mathrm{~kg}$ (male), wither heights of $55 \mathrm{~cm}$ (female) and $66 \mathrm{~cm}$ (male), body lengths of $50 \mathrm{~cm}$ (female) and $65 \mathrm{~cm}$ (male), and chest girths of $64 \mathrm{~cm}$ (female) and $76 \mathrm{~cm}$ (male). Thus, Gembrong ewes show sexual maturity at 18 months through reproductive traits such as gestation length of five months, oestrous length of 18 hours, and postpartum oestrous at 63 days, with 1-2 kids per parity [1]. However, there is no recent report on the origin of the Gembrong goat has recently. In addition, the mitochondrial DNA (mtDNA) of the Gembrong goat had subhaplogroup B1, which was similar to Kacang, Ettawa grade, Black Bengal (Bangladesh), and native Philippine goats [2].

\footnotetext{
*Corresponding author: widya.putra.lipi@gmail.com
} 
Unfortunately, the Gembrong goat is critically endangered. In 2017, the total number in Tumbu Village was 33 [3]. As a result of the small population size, there is a risk of inbreeding of Gembrong goats. Using primary data from a prior study, the purpose of this study was to estimate the inbreeding coefficient (Fx), inbreeding rate (IR), and inbreeding probability (PI) in the Gembrong population. The results of the study can develop breeding and conservation programs for Gembrong goats in the future.

\section{Materials and Methods}

The pedigree data of the Gembrong goat consisting of six ewes and three rams (Fig. 2) were obtained from a previous study in Tumbu village, Karangasem Regency, Bali Province of Indonesia, with a different scope [4]. As a result, the mating pathway in this study was designed based on Figure 3. Furthermore, twenty Gembrong goats consisting of eleven ewes and nine rams were monitored at Tumbu Village and used in this study to estimate the inbreeding coefficient(Fx), inbreeding rate (IR), and inbreeding probability (PI).

The inbreeding coefficient (Fx) value in an inbred kid was calculated using a mathematical formula [5] based on Figure 3:

$$
F_{i s}=\sum\left[(0.5)^{n+1}\left(1+F_{a}\right)\right]
$$

Where, Fis is the inbred kid; $\mathrm{n}$ is the number of line in the mating pathway; Fa is the inbreeding coefficient in the parental.

The inbreeding rate (IR) in Gembrong population was calculated using a mathematical formula [6] as follows:

$$
I R=\frac{1}{8\left(N_{S}\right)}+\frac{1}{8\left(N_{I}\right)}
$$

Where, IR is the inbreeding rate; Ns is the number of sire (ram); NI is the number of dam (ewe).

The inbreeding probability (PI) value in F1 Gembrong goat population was calculated using some mathematical formula [7] as follow:

$$
\begin{aligned}
& P_{I}=\frac{N_{M I}}{N_{M G}} \\
& N_{M P}=N_{S} \times N_{I} \\
& N_{M G}=\left(N_{M P}-1\right) \times\left(N_{M P} \times 0.5\right) \\
& N_{M I}=\left[\left(N_{S}+N_{I}\right)-2\right] \times\left(N_{M P} \times 0.5\right)
\end{aligned}
$$

Where, PI is the inbreeding probability; NMP is the number of mating pairs combination in parental; NMG is the number of mating pairs combination in first generation (F1); NMI is the number of inbreeding-mate pairs combination in F1 offspring; Ns is the number of sire (ram); NI is the number of dam (ewe). 


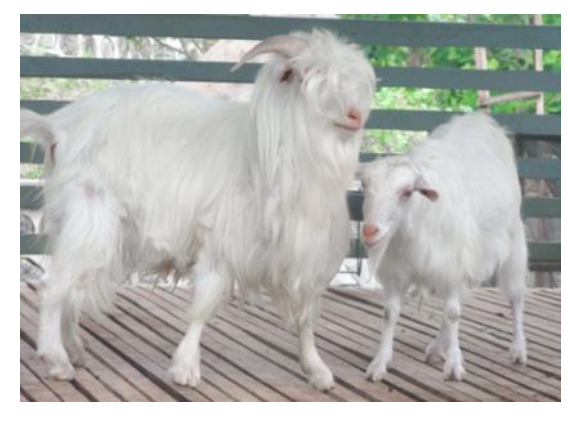

Fig. 1. A Gembrong ram (left) and ewe (right)

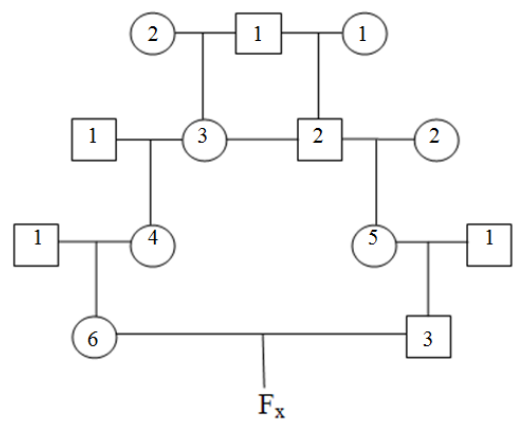

Fig. 2. The pedigree scheme in an inbred Gembrong kid (Fx) at Tumbu Village arranged from a previous study [4] with modification. Total of six ewes ( $(0)$ and three rams ( $\square$ ) were recorded as the parental of inbred kid. The numbers in the symbol are goats ID

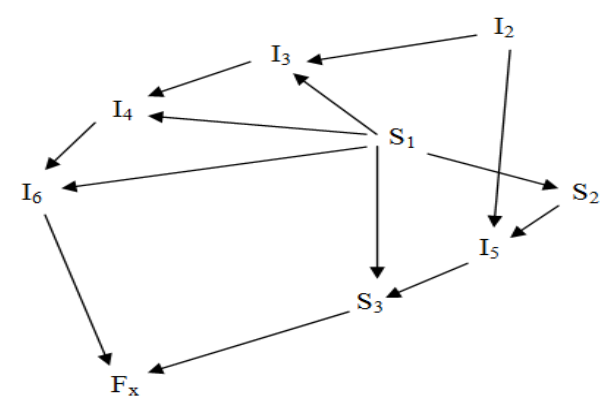

Fig. 3. The scheme of mating pathway in rams (S) and ewes (I) to produce an inbred kid (Fx). The numbers in the symbol are goats ID

\section{Results and Discussion}

Table 1 shows the inbreeding coefficient (Fis) value of an observed kid has an Fx value of 0.413. Meanwhile, the Fis value in an inbred Banteng calf at the Surabaya Zoo was 0.42 [8], 
comparable to the present study. When the Fx value is higher than 0.125 , it is classified as high [9]. Furthermore, a Fis value greater than 0.30 can reduce productivity, increase mortality, and genetic disorders [10]. Moreover, the Fis value of 0.125 caused the death of a Bali calf [11]. In most cases, genetic diversity in an inbred population was low, as seen by a large proportion of individuals with recessive homozygote frequency. As a result, the recessive homozygote allele harms the metabolic system, potentially causing mortality or genetic diseases.

Table 2 shows that the inbreeding rate (IR) in the Gembrong goat population was 0.025 . Meanwhile, the IR value in the Banteng population in the Surabaya Zoo was 0.043 [8], which was higher than the value in this study. An IR value greater than 0.02 [12] is high, and the inbreeding probability (PI) among F1 Gembrong goats was 0.184 , which was low (PI0.50). Inbreeding can be reduced by increasing the number of sires used to produce frozen sperm (straw). In a small population, a recording system is essential for managing mating combinations among animals. Regardless, crossbreeding with other breeds with similar characteristics is essential to maintain desirable traits. Alternatively, Angora ram sperm from Turkey or India might be imported to Indonesia for crossbreeding or grading-up programs. Furthermore, the Angora goat and the Gembrong goat have similar traits. However, genetic introgression from other purebred breeds will reduce the population of purebred Gembrong goats. In addition, the embryo transfer (ET) method can be applied to Gembrong goat as one of the conservation programs for Gembrong goats in the future.

Table 1. The inbreeding coefficient of in an inbred Gembrong kid

\begin{tabular}{|l|c|l|c|c|c|}
\hline $\begin{array}{c}\text { Common } \\
\text { ancestor }\end{array}$ & \multicolumn{1}{|c|}{$\mathrm{F}_{\mathrm{a}}$} & \multicolumn{1}{|c|}{ Mating pathway } & $\mathrm{N}$ & Contribution & $\mathrm{F}_{\text {is }}$ \\
\hline $\mathrm{S}_{1}$ and $\mathrm{I}_{2}$ & $\mathrm{I}_{4}(0.25)^{*}$ & $\mathrm{~S}_{3}-\mathrm{I}_{5}-\mathrm{S}_{2}-\mathrm{S}_{1}-\mathrm{I}_{6}$ & 5 & $(0.50)^{5}(1+0.25)$ & 0.039 \\
\hline & $\mathrm{I}_{6}(0.25)^{* *}$ & $\mathrm{~S}_{3}-\mathrm{I}_{5}-\mathrm{S}_{2}-\mathrm{S}_{1}-\mathrm{I}_{4}-\mathrm{I}_{6}$ & 6 & $(0.50)^{6}(1+0.50)$ & 0.023 \\
\hline & & $\mathrm{S}_{3}-\mathrm{I}_{5}-\mathrm{I}_{2}-\mathrm{I}_{3}-\mathrm{I}_{4}-\mathrm{I}_{6}$ & 6 & $(0.50)^{6}(1+0.50)$ & 0.023 \\
\hline & & $\mathrm{S}_{3}-\mathrm{I}_{5}-\mathrm{I}_{2}-\mathrm{I}_{3}-\mathrm{S}_{1}-\mathrm{I}_{6}$ & 6 & $(0.50)^{6}(1+0.25)$ & 0.019 \\
\hline & & $\mathrm{S}_{3}-\mathrm{I}_{5}-\mathrm{I}_{2}-\mathrm{I}_{3}-\mathrm{S}_{1}-\mathrm{I}_{4}-\mathrm{I}_{6}$ & 7 & $(0.50)^{7}(1+0.50)$ & 0.012 \\
\hline & & $\mathrm{S}_{3}-\mathrm{S}_{1}-\mathrm{I}_{6}$ & 3 & $(0.50)^{3}(1+0.25)$ & 0.156 \\
\hline & $\mathrm{S}_{3}-\mathrm{S}_{1}-\mathrm{I}_{4}-\mathrm{I}_{6}$ & 4 & $(0.50)^{4}(1+0.50)$ & 0.094 \\
\hline & $\mathrm{S}_{3}-\mathrm{S}_{1}-\mathrm{I}_{3}-\mathrm{I}_{4}-\mathrm{I}_{6}$ & 5 & $(0.50)^{5}(1+0.50)$ & 0.047 \\
\hline & \multicolumn{1}{|c|}{ Total } & 0.413 \\
\hline
\end{tabular}

${ }^{*}$ offspring $\times$ sire $; * *$ grandkid $\times$ grandparent $; \mathrm{F}_{\text {is }}$ : inbreeding coefficient for an inbred kid; $\mathrm{F}_{\mathrm{a}}$ : inbreeding coefficient of parent $; \mathrm{N}$ : number of individuals 
Table 2. The inbreeding rate (IR) in Gembrong goat population at Tumbu Village

$\mathrm{N}$ : number of individuals

\begin{tabular}{|c|c|c|}
\hline Sex & N & IR \\
\hline Male (ram) & 9 & 0.014 \\
\hline Female (ewe) & 11 & 0.011 \\
\hline \multicolumn{2}{|c|}{ Total } & 0.025 \\
\hline
\end{tabular}

\section{Conclusion}

The Gembrong goat in Tumbu Village was endangered due to its high IR and Fis values. Therefore, random mating will result in around $18 \%$ of inbred mates among F1 (offspring). In the future, the Gembrong goat recording system will be essential for reducing inbreeding.

\section{References}

1. KEMENTAN RI. Penetapan Rumpun Kambing Gembrong. (2013). http://bibit.ditjenpkh.pertanian.go.id/sites/default/files/Kambing\%20Gembrong.pdf

2. M.S.A. Zein, S. Sulandari, Jakaria, I.M. Londra, S. Guntoro, I.B.G. Partama, Jurnal Kedokteran Hewan, 10 (2016).

3. T.I. Putri, M. Dewantari. Peningkatan produktivitas kambing Gembrong yang terancam punah melalui suplementasi multi vitamin-mineral dalam ransum berbasis hijauan lokal. Majalah Ilmiah Peternakan, 20 (2017).

4. K.D.P. Dyantari, I.G. Lanang Oka, D.A. Warmadewi, Peternakan Tropika, 3 (2015).

5. W.D. Stansfield. Genetika. Erlangga, Jakarta (1991).

6. D. Tave. Inbreeding and Broodstock Management. FAO Fisheries Technical Paper. Rome, 392 (1999).

7. W.P.B. Putra, M. Firmansyah. Perhitungan matematika pada peluang inbreeding dalam populasi ternak generasi pertama. Limits, 17 (2020).

8. R. Sawitri, M. Takandjandji. Inbreeding pada populasi Banteng (Bos indicus d'Alton 1832) di Kebun Binatang Surabaya. Buletin Plasma Nutfah, 18 (2012).

9. M.A. Halverson, D.K. Skelly, A. Caccone, J. Heredity, 97 (2006).

10. R.R. Noor. Genetika Ternak. Penebar Swadaya, Jakarta. (2010).

11. W.P.B. Putra, Muzawar, Kocatepe Vet. J, 13 (2020).

12. E.B. Loeske, L.E. Kruuk, B.C. Sheldon, J. Merila. Severe inbreeding depression in collared fly catchers (Ficedula albicollis), In Proceedings of the Royal Society B: Biological Science, 22 March 2002, London, UK (2002). 